\title{
COMPOSITE RISER RELIABILITY UNDER HARSH ENVIRONMENTAL CONDITIONS
}

\author{
A. Sobey, H. Ragheb \& R. Shenoi, University of Southampton, UK \\ D.C. Pham, Institute of High Performance Computing, Singapore
}

\begin{abstract}
Offshore engineers are looking to explore resources further from shore and at greater depths. A number of papers have indicated that composite materials may provide benefits at these depths. However, there are only a small number of risers in-service and with no history of operation these applications require experiments and theoretical investigations to ensure the safety and increase the knowledge about how they will survive the deep-water conditions. This paper therefore investigates a simplified model for composite risers for application to reliability analysis. A static catenary model is used with classical laminate plate theory used to generate stresses in the composite. This is connected to a Monte Carlo Simulation which is used to compare composite risers in harsh and normal conditions.
\end{abstract}

\section{REFERENCES}

1. Tarnopol'skii, Y.M., Kulakov, V.L. \& Mungalov, D.D., 1999. Composites in offshore technology in the next century. Mechanics of Composite Materials, vol. 35, pp.365-372.

2. Beyle, A.I. Gustafson, C.G. Kulakov V.L. \& Tanopil’skii, Y.M. (1997) Composite risers for deep-water offshore technology: problems and prospects. 1. Metalcomposite riser, Mechanics of Composite Materials, vol. 33, pp. 403-414

3. Pham, D.C., Sridhar, N., Qian, X., Sobey, A.J., Achintha, M., R.A.Shenoi, 2016. A review on design, manufacture and mechanics of composite risers, Ocean Engineering, vol 112, pp. 82-96.

4. Xia, J. Das, P.K. and Karunakaran, D. (2008) A parametric design study for a semi/SCR system in Northern North Sea, Ocean Engineering, vol. 35, pp. 1686-1699

5. da Silva, R.F. Teofilo, F.A.F. Parente, E. de Melo, A.M.C. \& de Hollande, A.S. (2013) Optimization of composite catenary risers. Marine Structures, 33, pp.1-20.

6. Faltinsen, O., 1990. Sea Loads on Ships and Offshore Structures, Cambridge: Cambridge University Press.

7. Det Norske Veritas, 2010. EDNV-RPC205: Environmental Conditions and Environmental Loads, Oslo, Norway. DNV
8. Zhan, J.P., 2010. Review and verification of marine riser analysis programs : Global response analysis. Norwegian Univeristy of Science and Technology.

9. Pham, D.C., Su, Z., Narayanaswamy, S., Qian, X., Huang, Z., Sobey, A.J., Shenoi, R.A. (2016), Experimental and numerical studies of large-scaled filament wound T700/X4201 composite risers under bending. ECCM17 - 17th European Conference on Composite Materials, Munich, Germany, 26-30th June 2016

10. Philippidis, T.P., Lekou, D.J. \& Aggelis, D.G., 1999. Mechanical property distribution of CFRP filament wound composites. Composite Structures, 45(1), pp.41-50.

11. Wang, Y., Gao, D. \& Fang, J., 2014. Static analysis of deep-water marine riser subjected to both axial and lateral forces in its installation. Journal of Natural Gas Science and Engineering, 19, pp.84-90. Available at: http://dx.doi.org/10.1016/j.jngse.2014.04.0 19.

12. Buberg, T., 2014. Design and Analysis of Steel Catenary Riser Systems for Deep Waters. Norwegian University of Science and Technology. 